\section{Starters in}

\section{Amsterdam:}

\section{nieuwe}

\section{ongelijkheden?}

CASUS Cody Hochstenbach

Schier eindeloze wachttijden, exorbitante huurprijzen en drukbezochte woningbezichtigingen. Krapte op de Amsterdamse woningmarkt zorgt ervoor dat starters moeite hebben met het volgen van een wooncarrière in de stad. Via rommelige woontrajecten en slimme zoekstrategieën weten veel jonge huishoudens toch hun weg te vinden.

Het afgelopen jaar verwelkomde Amsterdam, eerder dan verwacht, haar 800.000 ste inwoner. Als gevolg van een versnellende bevolkingsgroei van Amsterdam wordt de woningmarkt steeds krapper. Beleidsmatig bestaan er zorgen dat vooral jonge, startende huishoudens in toenemende mate moeite hebben met het verkrijgen van toegang tot de Amsterdamse woningmarkt en, vervolgens, met het maken van een wooncarrière binnen de stad. Het ontbreken van een passend betaalbaar aanbod en een woningmarkt die op slot zit, zouden ervoor zorgen dat jonge huishoudens vast komen te zitten in een benarde positie op de woningmarkt.

Het is dan ook opmerkelijk dat juist het aantal jonge, startende huishoudens bovengemiddeld toeneemt en dat zij bovendien veelal nog steeds in staat zijn een woning te vinden in de meest populaire buurten van de stad. Zo trekken populaire en prijzige buurten als de Jordaan, de Pijp en de Rivierenbuurt onverminderd veel starters (Figuur links) en net afgestudeerden (Figuur rechts). Daarnaast verhuizen veel starters naar opkomende, gentrificerende buurten als De Baarsjes (in Oud West) en de Indische Buurt (in Oost).

Hoe is het mogelijk dat starters, ondanks hun benarde positie op de woningmarkt, zo goed in staat zijn in de populairste buurten van de stad een woning te vinden? Op basis van interviews met starters blijkt dat de ideaaltypische lineaire wooncarrière, waarbij iedere verhuizing een verbetering van de woonsituatie met zich meebrengt, niet meer voldoet. Het concept van 'housing pathways', vrij vertaald woontrajecten, vormt een geschikter analytisch kader.
Woontrajecten verlopen rommelig en worden gekenmerkt door (onverwachte) onderbrekingen, tijdelijke woonsituaties en stappen terug. Desondanks weten veel starters deze chaotische woontrajecten juist in hun voordeel te gebruiken. Opvallend genoeg spelen financiële middelen hierbij veelal geen doorslaggevende rol. Het werk van de Franse socioloog Bourdieu is van belang bij het zoeken naar een betere verklaring. Bourdieu definieert, eenvoudig gezegd, een reeks kapitaalvormen. Naast economisch kapitaal bestaan ook sociaal, cultureel en symbolisch kapitaal. Het al dan niet bezitten van deze andere kapitaalvormen blijkt een nauwkeurigere verklaring te bieden voor de mate van succes op de woningmarkt voor jonge huishoudens.

\section{Onderbreking van de wooncarrière}

Verschillende factoren maken het volgen van een lineaire wooncarrière binnen de Amsterdamse woningmarkt vooral voor starters moeilijk. Zo bevindt 47 procent van de woningvoorraad zich in de sociale huursector, waarvoor een gemiddelde wachttijd van 11,5 jaar geldt. In de populairste delen van de stad is dit zelfs meer dan 16 jaar (als er al woningen vrij komen). Bovendien geldt er een vastgesteld maximum jaarinkomen (€34.229 in 2013). De koopsector is het afgelopen decennium aanzienlijk gegroeid tot bijna 30 procent van de voorraad. Dit gaf in eerste instantie startende huishoudens de kans een woning te kopen. De financiële crisis heeft het verkrijgen van een hypotheek echter bemoeilijkt. Bovendien biedt de koopsector doorgaans niet de flexibiliteit die starters zoeken.

De vrije huursector is niet alleen klein maar doorgaans ook duur, waarbij het ontbreekt aan een middensegment. De meeste huurwoningen die op de markt komen hebben een kale huur van meer dan $€ 900$ per maand. Er bestaat wel een goedkopere vrije huursector zonder officiële wachtlijst, de zogenaamde particuliere kernvoorraad, maar deze woningen worden vaak onderhands verhuurd en komen daardoor niet op de markt terecht.

Opvallend is de wijze waarop veel starters bovendien uitgesloten worden van een woning in de vrije huursector. Strenge inkomenseisen en andere aanvullende voorwaarden vormen hier het grootste struikelblok, zo blijkt onder andere uit het volgende citaat: 'in principe stonden we er best voor open om $€ 1000$ per maand te betalen, dat was nog binnen onze range [...] maar ja, aan die inkomenseis [van €50.000] gingen wij nooit voldoen'. Een logische eerste stap in de wooncarrière na afstuderen wordt zo afgesneden, ook al is de huur betaalbaar.

\section{Starters tuimelen van de ene onzekere, precaire en dure woonvorm in de andere}

\section{Mogelijke alternatieve woontrajecten}

Als gevolg van deze barrières en valkuilen is het voor veel starters onmogelijk een lineaire wooncarrière te volgen. Op zoek naar woonruimte komen zij vervolgens terecht in de (semi-)illegale sectoren van de woningmarkt. Hier komt het voor dat starters keer op keer verhuizen naar tijdelijke kamers, bijvoorbeeld wanneer kennissen tijdelijk naar 

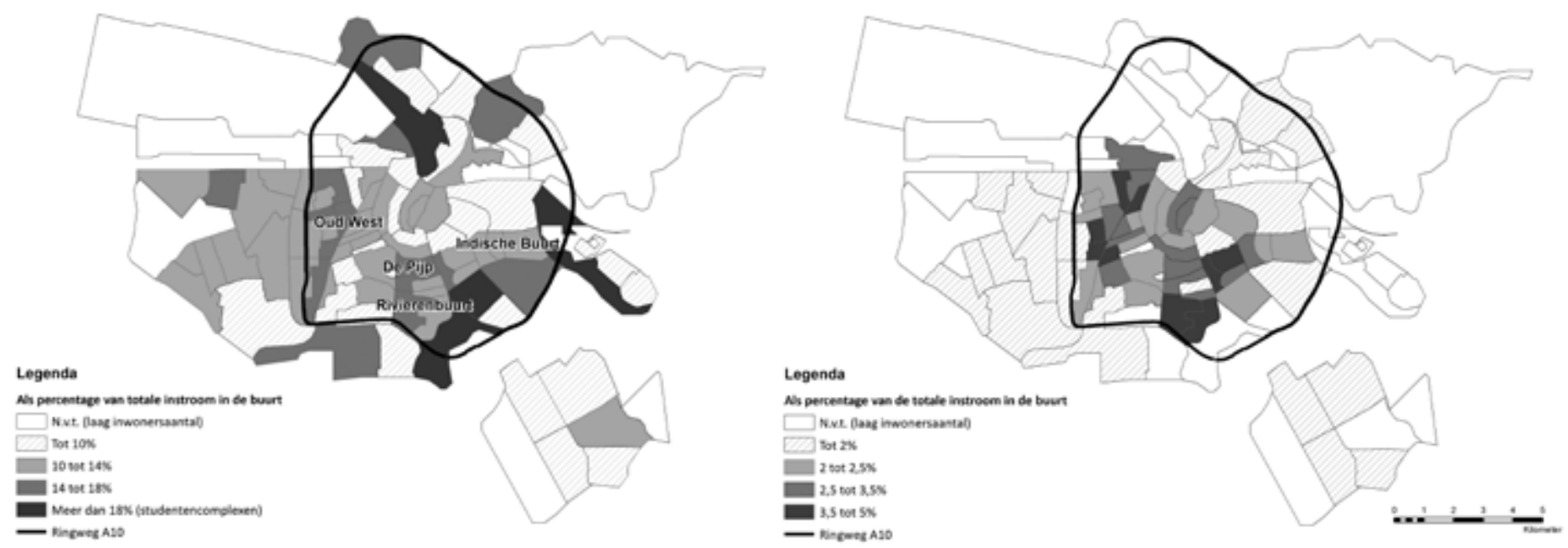

Figuur 1. Instroom van starters (verlaters van het ouderlijk huis) in 2010 links en de instroom van recent afgestudeerden in 2010 rechts. Bron: Sociaal Statistisch Bestand, CBS (2013)

het buitenland gaan. Anderen krijgen te maken met schimmige verhuurpraktijken van louche pandjesbazen. Deze starters tuimelen van de ene onzekere, precaire (maar doorgaans dure) woonvorm in de andere. Een plotselinge huisuitzetting dwingt hen namelijk ook mindere opties te accepteren om niet zonder huis komen te zitten.

Desalniettemin zijn er eveneens veel starters die doelbewust in de grijze subsector van de woningmarkt zoeken en zo een chaotisch woontraject opbouwen. Het niet-gereguleerde karakter van deze 'sector' is voor hen juist aantrekkelijk. Zij huren liever een 'illegale' woning in een aantrekkelijke buurt, dan een reguliere woning ver van de binnenstad. Of, zoals één respondent stelt: 'via officiële wegen [zoeken] heeft echt geen enkele zin' - de beste opties zijn voor hen toegankelijk via het grijze circuit. Hierbij handelen ze vaak creatief om uit het zicht te blijven van de autoriteiten. Het komt bijvoorbeeld voor dat starters een relatie veinzen met de verhuurder om uit het zicht van de gemeente en belastingdienst te blijven. Illegale onderhuur biedt starters kansen, bijvoorbeeld om samen te gaan wonen zonder een lange lijst aan voorwaarden of om op leuke plekken te wonen. Deze starters nemen het onzekere, chaotische en veelal illegale karakter van deze woontrajecten voor lief om van de voordelen gebruik te kunnen maken. Bovendien weten deze jonge huishoudens keer op keer, bij iedere al dan niet noodgedwongen verhuizing, een aantrekkelijke woning te vinden.

\section{Succesvolle chaotische woontrajecten?}

Hoe is het mogelijk dat deze starters ondanks de grote onzekerheid een succesvol woontraject kunnen opbouwen? Een belangrijk element is dat deze starters bewust kiezen voor een chaotisch woontraject, deze zorgt er namelijk voordat zij constant anticiperen op een volgende verhuizing. Zo behouden zij een zekere mate van controle, zelfs na een huisuitzetting. Bovendien stelt deze bewuste keuze hen in staat niet-economische kapitaalvormen in te zetten. Deze andere kapitaalvormen zijn vooral nuttig in dit grijze, ondoorzichtige circuit.

Het merendeel van deze groep starters geeft aan via via een woning gevonden te hebben, wat het belang van sociaal kapitaal benadrukt. Dit gaat verder dan het zoeken naar woonruimte binnen de eigen directe vrienden- of kennissenkring. Succesvolle starters geven aan dat het van groot belang is een 'zo breed mogelijk netwerk' te hebben en daarbinnen voortdurend te zoeken naar mogelijke woonopties. Vooral de goedkope particuliere kernvoorraad speelt hierbij een belangrijke rol, aangezien hier de verhuurders de woningen doorgaans onderhands verhuren. Eén respondent wist hiertoe toegang te verkrijgen via de ouders van zijn vriendin: 'ze hadden mij helemaal boven aan de wachtlijst gezet [...] die mensen dachten gewoon "die jongen moet een nieuw huis hebben" [...]. Ik heb er eigenlijk niets voor hoeven doen'. Dit citaat geeft aan dat succesvolle starters, door te anticiperen op een verhuizing en het netwerk aan te spreken met weinig moeite een (goedkoop) appartement weten te verkrijgen.

\section{Kennis van zaken}

Veel succesvolle starters geven bovendien aan te kiezen voor opkomende buurten: 'lk vind Oost ontzettend leuk [en] het gaat er ongelofelijk snel. Het is net de Pijp maar dan met grotere huizen en iets minder druk. De leuke horeca schiet hier ook uit de grond'. Dergelijke kennis van de Amsterdamse woningmarkt kan gezien worden als een toegepaste vorm van cultureel kapitaal. Zo weten starters met veel cultureel kapitaal bijvoorbeeld beter welke buurten in opkomst zijn en kunnen zij anticiperen op toekomstige gentrification processen en een buurthype en sterke prijsstijgingen voor zijn. Starters met minder kennis of cultureel kapitaal lopen daarop achter en leren deze buurten pas kennen wanneer ze al populair zijn en het inmiddels lastig is daar een woning te verkrijgen. Ook andere vormen van cultureel kapitaal spelen een rol, zoals kennis van regelgeving en voorrangsregelingen. Op die manier wisten verschillende starters een urgentiestatus (een voorrangsregeling) voor de sociale huursector te bemachtigen.

Het kiezen voor de informele grijze sector gaat daarnaast gepaard met een zekere bereidheid de regels te overtreden. Dit kan 'crimineel kapitaal' genoemd worden. Het komt daarnaast ook voor in meer extreme vormen, zoals bij het volgende starterskoppel: '[wij] kenden via 
via een makelaar en die [handelde] in goedkope huurwoningen. [...] Daarvoor vroeg hij een vergoeding [van €12.000], dat mocht officieel niet. Maar goed, dat hebben we maar gedaan anders kwamen we er niet in'. Dit stel accepteerde dit als een normaal onderdeel van het spel. Het (rechtmatig) terugvorderen van het bedrag wordt neergezet als een overtreding van de spelregels: 'wij hebben ermee ingestemd, dus dat vond ik dan wel heel flauw om te zeggen "ik ga het toch lekker terugvragen", dus dat heb ik niet gedaan'. Naast economisch kapitaal (de financiële vergoeding) speelden sociaal kapitaal en crimineel kapitaal een essentiële rol bij het verkrijgen van deze woning. Dergelijk crimineel kapitaal is voor veel starters van grote betekenis bij het vinden van een woning.

\section{Economisch, sociaal en crimineel kapitaal spelen een rol bij het verkrijgen van een woning.}

\section{Gevolgen en beleid}

Economisch kapitaal is dus onder starters niet de drijvende kracht achter het vinden van een woning. Alternatieve kapitaalvormen zijn daarentegen wel essentieel voor een succesvol woontraject. Zij kunnen fungeren als vervanging voor economisch kapitaal - starters hebben doorgaans immers (nog) geen hoog inkomen of groot vermogen. Dit faciliteert de formatie van chaotische woontrajecten die zich grotendeels afspelen in het grijze circuit. In de reguliere, officiële sectoren van de woningmarkt zijn alternatieve kapitaalvormen namelijk van minder nut.

De druk op de woningmarkt zet veel starters aan een dergelijk chaotisch traject te volgen - dit zorgt ervoor dat de alternatieve kapitaalvormen belangrijker worden. Hierdoor ontstaat er een groeiende ongelijkheid tussen starters op niet-financiële basis. Zo hebben starters die opgegroeid zijn in Amsterdam of de regio doorgaans een groter sociaal netwerk ter beschikking en hebben zij meer kennis van de stad en de lokale woningmarkt. Het belang van alternatieve kapitaalvormen zorgt echter ook voor een groeiende ongelijkheid op basis van sociale achtergrond. Starters afkomstig uit een hoger opgeleid milieu bezitten bijvoorbeeld eerder de benodigde overige kapitaalvormen dan starters uit minder hoogopgeleide milieus. Dit kan ertoe leiden dat klassenverschillen sterker benadrukt worden, terwijl deze in een latere levensfase al tot uiting komen op basis van economisch kapitaal. Tevens hebben studenten een voordeel ten opzichte van niet-studenten. Starters die niet gaan studeren en direct gaan werken, hebben doorgaans andere woonvoorkeuren. Zij willen bij het verlaten van het ouderlijk huis vaak direct een zekere woonsituatie. Het resultaat is dat zij achteraan moeten sluiten in de wachtrij voor sociale woonruimte, of op zoek moeten naar een duurdere huur- of koopwoning.

Het belang van chaotische woontrajecten en de daaropvolgende nieuwe ongelijkheden voegen een nieuwe dimensie toe aan de discussies over de positie van starters op de Amsterdamse woningmarkt. Het idee van een wooncarrière met een reeks logisch op elkaar volgende stappen voldoet niet. Toch is het beleid van overheden en woningcorporaties hierop gericht. Er lijkt consensus te bestaan dat het aanbod middensegmentwoningen (met een huur tussen de €700 en €900) vergroot dient te worden om starters en middeninkomens plek te bieden.

Ook initiatieven als 'woningdelen' en tijdelijke 'vijf-jaren contracten' faciliteren een dergelijke vervolgstap in de wooncarrière. Dit zal echter niet het einde van de chaotische woontrajecten betekenen. De huren in de vrije sector blijven fors, de vraag groot, en alternatieve kapitaalvormen kunnen nauwelijks ingezet worden. Dit zal er voor zorgen dat sommige starters nog steeds uit noodzaak een chaotisch woontraject moeten doorlopen of er juist bewust voor kiezen. Het gevaar bestaat dan ook dat de almaar toenemende druk op de woningmarkt, ondanks deze nieuwe beleidsinitiatieven, een grotere afhankelijkheid van chaotische woontrajecten bewerkstelligt en zo verschillende vormen van ongelijkheid versterkt.

Cody Hochstenbach (c.hochstenbach@uva.nl) is promovendus stadsgeografie aan de Universiteit van Amsterdam. Dit artikel is gebaseerd op het onderzoeksrapport 'Duurzame Toegankelijkheid van de Amsterdamse Woningmarkt voor Starters' uit 2013.

\section{Literatuurselectie}

Boterman, W.R., C. Hochstenbach, R. Ronald \& M. Sleurink (2013)

Duurzame toegankelijkheid van de Amsterdamse woningmarkt voor starters. Amsterdam: Centre for Urban Studies Universiteit van Amsterdam

Boterman, W.R. (2012) Deconstructing coincidence: How middle-class households use various forms of capital to find a home. Housing, theory and society, 29(3), pp. 321-338

Bourdieu, P. (1986) The forms of capital, in: J. G. Richardson (ed.) Handbook of theory and research for the sociology of education, New York: Greenwood, pp. 241-258

Clapham, D. (2002) Housing pathways: A post modern analytical framework. Housing, theory and society, 19(2), pp. 57-68 